УДК 373.542

DOI: 10.37026/2520-6427-2020-103-3-105-109
Ірина ОЗАРЧУК,

асистентка кафедри іноземних мов

Національного університету водного господарства та природокористування, м. Рівне

\title{
ОСОБЛИВОСТІ НАВЧАННЯ ОБДАРОВАНИХ УЧНІВ У ЛАТВІЙСЬКІЙ РЕСПУБЛІЩІ
}

\begin{abstract}
У статті висвітлено сучасні підходи до проблеми дитячої обдарованості, прийняті у вітчизняній психології та педагогіщі. Схарактеризовано специифіку роботи закладів освіти, як-от Факультативної школи ABFS, Школи для обдарованих дітей, Спеціальної школи для «дітей індиго» та ін., щзо здійснюють підготовку обдарованої учнівської молод $i$ у Латвійській Республічі. Окреслено необхідність реалізачії в означених закладах творчого підходу та забезпечення сприятливих умов для розвитку здібностей обдарованих дітей.
\end{abstract}

Ключові слова: обдарованість, обдаровані діти, Латвійська Республіка, заклади, шо здійснюють підготовку обдарованих дітей, спеціальні класи.

B статье освещены современные подходы $\kappa$ проблеме детской одаренности, принятые в отечественной психологии и педагогике. Охарактеризована специфика работь учебных заведений, например, Факультативной школь $A B F S$, Школь для одаренных детей, Спечиальной школь для «детей индиго» и др., осуществляюших подготовку одаренной учащейся молодежи в Латвийской Республике. Определена необходимость реализачии в указанных заведениях творческого подхода и обеспечения благоприятных условий для развития способностей одаренных деmeй.

Ключевые слова: одаренность, одаренные дети, Латвийская Республика, заведения, осущчествляюшие подготовку одаренных детей, специиальные классы.

The article highlights modern conceptual approaches to the problem of child giftedness, adopted in domestic psychology and pedagogy. Emphasisis placed on intellectual talent, inparticular, the drawings express the idea of the integrity of the study. The target priorities and content-procedural aspects of the activity of Latvian organizations in the field of education of gifted and talented people are highlighted. school children. Favorable social and psychological conditions for the development of creative talent of students are characterized. The specifics of work with gifted students of Latviain the optional school ABFS, "school for gifted children», "Action program for work with gifted students of educational institutions of Ventspils», a special school for «indigo children» are presented. Special attention in the special school for "indigo children» is aimed at the development of children with a high level of intelligence and highly developed intuition, who love freedom and do not recognize authority. The need to implement a creative approach in the process of providing favorable conditions for the development of abilities and talents of children is shown.

It is established that the seorganizations have a common mission - to develop the potential of gifted and talented children through the organization of cooperation of all participants in this process - teachers, parents, scientists, the public, educational politician sand gifted people. It was found that the most common for msofexchange of experience are regular international, national and regional conferences, which also involve all participants in this process, as well as the publication of specialized scientific publications on the education of gifted and talented.

Key words: giftedness, gifted children, the Republic of Latvia, institutions that train gifted children, special classes.

Постановка проблеми. XXI століття відзначається швидким зростанням світової глобалізації та інтенсивним ростом конкуренції. У зв'язку з цим спостерігається неабиякий попит на інновації, який стає одним із головних каталізаторів досліджень обдарованості в третьому тисячолітті. У сучасних умовах розкриття інтелектуального та творчого потенціалу особистості $€$ пріоритетом національної освітньої політики багатьох країн світу. Педагоги та науковці ставлять перед собою завдання творчого пошуку оригінальних, нестандартних рішень щодо розвитку обдарованості, спонукають до появи нових технологій, оригінальних виховних ідей, форм і методів навчання й виховання.

Ретельне вивчення ролі закладів освіти, які здійснюють підготовку обдарованої учнівської молоді в країнах Балтії, зокрема у Латвійській Республіці, дослідження змісту, форм і методів підготовки обдарованої учнівської молоді, розгляд ії структури і особливостей, ознайомлення із формами позакласної й позашкільної роботи, запозичення сучасних педагогічних технологій, що застосовуються у європейському освітньому просторі сприятимуть подальшому розвитку освіти України і суспільства загалом у дусі поваги до правової держави й підготовки молоді до життя й діяльності в умовах європейської інтеграції [7].

Аналіз наукових досліджень і публікацій. Різні аспекти проблеми освіти обдарованих і талановитих особистостей висвітлені в численних наукових публікаціях як зарубіжних, так і вітчизняних дослідників. Зокрема, на сьогодні вченими досліджено природу обдарованості (В. Александер, Г. Вебб, Д. Векслер, М. Замелюк, Дж. Міллер, Р. Пріма, Д. Хендриксон, Р. Хеттел, Е. Шафер та ін.); визначено сутність обдарованості 
та виявлено специфічні особливості обдарованої дитини (Д. Богоявленська, М. Замелюк, А. Карне, Н. Лейтес, Ф. Монкс, В. Панов, К. Перлет, А. Савенков, К. Хеллер, Е. Щебланова, В. Юркевич та ін.); розглянуто проблеми структури і природи здібностей та умов їх розвитку (Б. Ананьєв, В. Крутецкий, А. Леонтьєв, К. Платонов, С. Рубінштейн, Б. Теплов, В. Шадриков та ін.); окреслено загальні закономірності розвитку обдарованості (А. Брушлинский, Л. Виготський, В. Дружинін, Н. Лейтес, Р. Стенберг, Дж. Фрімен та ін.); розкрито питання практичного вивчення проблеми обдарованості (Ю. Бабаєва, Л. Долгополова, А. Жигайлова, М. Замелюк, І. Нікольська, В. Орлов, В. Панов, Т. Поярова, А.Савенков, Т. Хромова, В. Юркевич, Е. Яковлєва, В. Ясвин та ін.).

Незважаючи на значну кількість праць з означеної проблеми, питання діяльності закладів освіти Латвії, які займаються вихованням талановитих і обдарованих дітей, на сьогодні висвітлено не повною мірою, що й спонукало нас до написання означеної статті.

Мета статті - проаналізувати цільові пріоритети та специфіку роботи закладів освіти, що здійснюють підготовку обдарованої учнівської молоді у Латвійській Республіці.

Виклад основного матеріалу. Інноваційний тип освіти XXI століття передбачає здатність людини до пошуку нових знань, творення, оволодіння рефлексією як механізмом постійних роздумів над своїми діями і вчинками. Саме тому головним завданням освіти має бути не лише пізнання законів природи і суспільства, а насамперед особистісно-діяльнісне оволодіння гуманістичною методологією творчого перетворення освіти і гармонізації відносин «людинаприрода - суспільство» [13].

На сьогодні більшість науковців визнає, що рівень, якісна своєрідність і характер розвитку обдарованості - це завжди результат складної взаємодії спадковості (природних задатків) і соціального середовища, опосередкованого діяльністю дитини (ігрової, навчальної, трудової). Разом із тим не варто ігнорувати і ролі психологічних механізмів саморозвитку особистості, в основу якої покладено формування і реалізацію індивідуального обдарування.

Отже, креативність (творчий потенціал) людини визначають як один із найважливіших і певною мірою незалежний фактор обдарованості. Наприклад, американський психолог П. Торренс під креативністю розуміє процес, зумовлений неабиякою потребою людини в знятті напруги, що виникає в результаті невизначеності та дефіциту інформації та передбачає пошук і визначення проблеми, висунення і перевірку гіпотез щодо шляхів іiї вирішення, обгрунтування рішень.

Водночас у низці досліджень (М. Замелюк, Р. Пріма та ін.) було продемонстровано важливу роль мотиваційно-особистісних факторів і умов соціального оточення обдарованих дітей у реалізації їх потенціалу. Зокрема, А. Танненбаум, займаючись вивченням обдарованості, застосував психосоціальний підхід. На його думку, успіх залежить від наявності п’ятьох чинників (див. рис. 1), відсутність хоча б одного з яких зазвичай призводить до поразки.
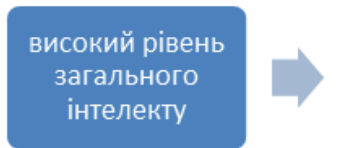

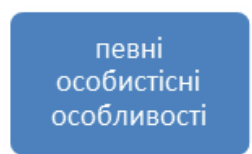

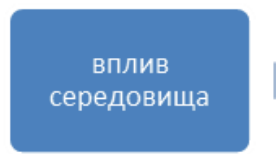

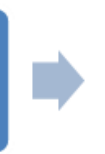

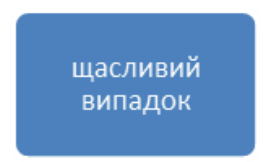

Рис. 1. Поняття обдарованості за А. Танненбаумом

Таким чином, для того, щоб творча обдарованість змогла себе проявити і далі розвиватися, потрібні сприятливе культурне оточення, опіка і заохочення, а іноді - й тиск зовні. Безперечно, що особливу роль у цьому відіграє домашнє середовище, насамперед батьки, їхній вплив і поведінка [3].

Разом із тим, психологами було доведено, що рівень, якісна своєрідність і характер розвитку обдарованості - це завжди результат складної взаємодії спадковості (природних задатків) і соціального середовища, опосередкованого діяльністю дитини (ігрової, навчальної, трудової). Однак при цьому не варто ігнорувати і ролі психологічних механізмів саморозвитку особистості, покладених в основу формування і реалізації індивідуального обдарування [3].

А. Матюшкін, розглядаючи обдарованість як загальну передумову творчого розвитку і становлення творчої особистості, виділяє п'ять ії структурних елементів (див. рис. 2):
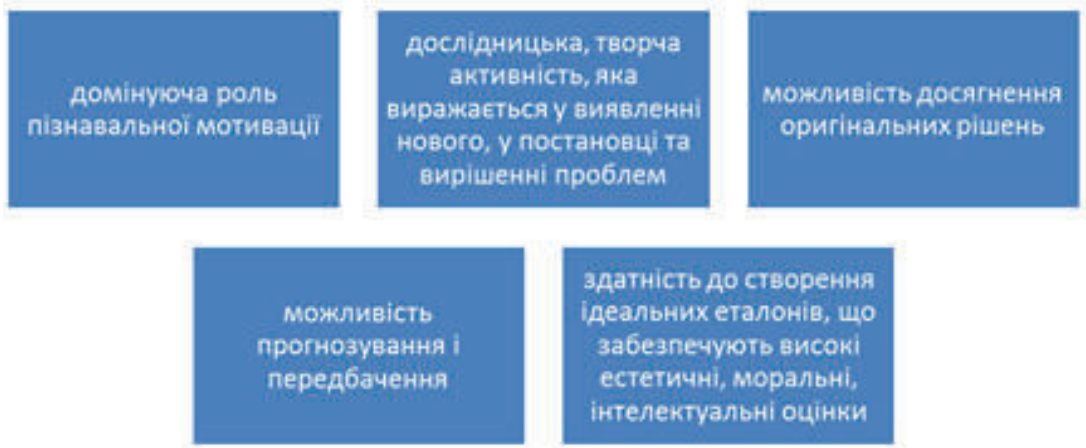

Рис. 2. Поняття обдарованості за А. Матюшкіним

Запропонована ним концепція творчої обдарованості передбачає розробку та реалізацію спеціальних творчих програм і навчальних матеріалів, а також являє собою теоретичну основу практичної допомоги талановитим дітям у створенні умов для розвитку їх творчого потенціалу. Саме це зосереджує нас на думці про те, що творчий потенціал дітей можна характеризувати різними рівнями прояву їх загальної 
обдарованості, творчих можливостей та здатностей, а його розвиток нерозривно пов'язаний із проблемою розвитку здібностей дитини [3].

Таким чином, обдарованість - це системна якість психіки, що розвивається протягом усього життя і визначає можливість досягнення людиною більш високих результатів в одному чи кількох видах діяльності в порівнянні з іншими людьми, а обдарована дитина - це дитина, яка вирізняється яскравими, іноді видатними досягненнями (або має внутрішні передумови для таких досягнень) у тій чи іншій сфері діяльності [11].

Тенденції суспільного розвитку переконують у зростанні ролі молоді в подальшому розвитку будь-якого суспільства. Так, для України цікавим $\epsilon$ досвід зарубіжних країн у підтримці талановитої молоді. Зважаючи на це, розглянемо, як цей процес проходить на теренах країн Балтії, зокрема у Латвійській Республіці.

Основу політики Латвійської Республіки в галузі розвитку фундаментальної і прикладної науки та технологій, а також системи освіти віднесено до стратегічних національних пріоритетів країни поряд iз підвищенням якості життя населення, досягненням економічного зростання, розвитком культури, забезпеченням оборони та безпеки країни. Однак в останні десятиліття скорочення чисельності зайнятих у науці фахівців, зокрема молодих кадрів, набуло загрозливого характеру, що істотно впливає на стан технологічної безпеки держави. Це викликає необхідність формування у Латвії спеціальної галузі державної політики підтримки талановитих та обдарованих дітей.

Виявлення талановитих та обдарованих дітей у Латвійській Республіці відбувається на підставі: конкурсних іспитів, освітніх результатів, спеціального тестування, думок педагогів.

Проаналізуємо цільові пріоритети та специфіку роботи деяких закладів освіти у Латвійській Республіці, що здійснюють підготовку обдарованої учнівської молоді.

В основу програми «Обдарована дитина» Факультативної иколи ABFS покладено концепцію обдарованості американського психолога Джозефа Рензулли, де під обдарованістю дитини розуміється поєднання в неї трьох характеристик: інтелектуальних здібностей вище середнього рівня; високих творчих здібностей; високої мотивації (цілеспрямованості). Тобто такі риси притаманні дітям-дослідникам, яких хвилюють глобальні теми, на кшталт, як влаштований світ; вони відзначаються підвищеною мотивацією до занять; їм усе цікаво і їх не потрібно спеціально розважати і зацікавлювати. Означена освітня програма розробленими для спеціальних груп дітей, однак вона цілком підійде і для занять зі звичайними дітьми.

Основний метод програми «Обдарована дитина»це метод дослідження. Зокрема, процес пізнання проходить у вигляді активної діяльності учнів: експериментальна робота в лабораторіях, робота з інформаці$є ю$, різні види моделювання природних і суспільних явищ. Як наслідок - діти самостійно здійснюють наукові відкриття. А це, як відомо, надзвичайно ефективний підхід, адже давно доведено: те, що ти відкрив самостійно, залишається з тобою на все життя. Серед пріоритетних цілей навчання дітей із обдарованістю у Факультативній школі варто виокремити передусім такі: розвиток духовно-моральних основ особистості обдарованої дитини, вищих духовних цінностей; створення умов для розвитку творчої особистості; розвиток індивідуальності обдарованої дитини; забезпечення широкої загальноосвітньої підготовки високого рівня, що обумовлює розвиток цілісного світорозуміння і високого рівня компетентності учнів.

Один із головних принципів програми - включення в освітній процес так званих глобальних тем, які стають ії основою. Зазначимо, що для всіх дітей найголовнішою метою навчання і виховання є забезпечення умов для розкриття і розвитку всіх здібностей та обдарувань 3 метою їх подальшої реалізації в професійній діяльності. Таким чином, підтримати і розвинути індивідуальність дитини, не розгубити, не загальмувати розкриття ііі здібностей - найважливіше завдання у навчанні обдарованих дітей Факультативної школи ABFS.

Крім того, у цій школі немає викладання окремих предметів як таких, а наявні міждисциплінарні заняття. Щороку вчителі-предметники збираються і обмірковують, яким змістом варто наповнити програму. При цьому незмінним лишається одне - включення до програми «великих цивілізацій», як-от Стародавній Сгипет чи Стародавня Греція, адже їх вивчення наповнює життя дитини значним освітнім ефектом.

Програма школи щороку оновлюється, оскільки дітей не вчать одному й тому ж, адже діти змінюються, ростуть, а отже, наповнюють своє шкільне життя низкою нового. Крім того, з'являються нові технології, наприклад, варто відзначити появу нової комп'ютерної програми, яка дає змогу спостерігати зоряне небо таким, яким воно було шість тисяч років тому, тобто таким, яким його бачили давні єгиптяни. Розповісти, звичайно, про це можна, а от спостерігати наочно, на екрані - набагато емоційніше [4, с. 101].

Факультативна школа ABFS передусім навчає дітей досліджувати і мислити, а щодо вибору майбутньої професії (лінгвістика чи соціологія, математика чи медицина), то вони визначаються із цим самостійно. Але вже тепер можна стверджувати, що після закінчення такої школи діти зроблять правильний вибір.

Варто зауважити, що в школах країн Балтії сьогодні неабиякої популярності набувають спеціальні класи, в яких дітей навчають, об'єднуючи в групи, залежно від здібностей. Тобто, навчаючись в одному класі з іншими дітьми, найбільш обдаровані отримують можливість займатися за спеціальною програмою. Ефект від такої форми навчання, на думку фахівців, неймовірний [4]. Одна із таких шкіл є в Ризі, вона так і називається - Школа для обдарованих дімей. Набір до цієї школи здійснюється на основі іспитів, а відвідувати заняття, які проходять у вигляді факультативів, діти мають можливість раз на тиждень.

У латвійському місті Вентспілс існує заклад освіти, який діс на основі Програми дій по роботі 3 обдарованими учнями освімніх установ самоврядування міста Вентспілс. Він працює за добровільним принципом: учнем цієї школи може стати кожен бажаючий, але при цьому виникає інше питання - чи кожна дитина почуватиметься тут комфортно. На сьогодні за означеною вище програмою навчається приблизно кожен четвертий школяр. Щодо дитячих садків і перших класів, то програмою охоплені фактично всі вихованці закладів дошкільної освіти та учні перших класів. Основна увага при цьому приділяється творчим здібностям і здатності мислити, адже саме мислення породжує інтерес до навчання [10, с. 21]. 
Цікавим закладом для обдарованих дітей у Латвії є також Ризький ліцей імені О. С. Пушкіна. Тут діти опановують надзвичайно складну програму з поглибленим вивченням математики та іноземних мов. Дітей, які закінчують даний ліцей, хочуть бачити серед своїх студентів кращі ЗВО не тільки Латвії, а й усієї Європи [12].

Прикладом ще однієї неординарної школи для талановитих дітей у Латвійській Республіці є Cnеціальна школа для "дітей індиго» (до речі, таких дітей у різних країнах називають по-різному: «діти нової свідомості» - у Росії, «діти тисячоліття» - у Великобританії, «діти світла» - в Японії, «тефлонові діти» - у Франціï). Тут навчаються діти з високим рівнем інтелекту і надзвичайно розвиненою інтуїцією. У них немає загальноприйнятих норм поведінки, вони люблять свободу і не визнають авторитетів. У звичайній школі такі діти вчитися просто не можуть, адже їм нудно.

Уроки в такій школі також дещо відрізняються від звичайних. Наприклад, на уроці математики діти різного віку займаються в одному класі, при цьому кожен розв'язує завдання зі свого підручника. А ще тут старші діти допомагають розібратися зі складними завданнями молодшим. У кожного учня - власна освітня програма: формально він - учень шостого класу, хоча хімію вивчає за п'ятий, а фізику - за сьомий. Як не дивно, але дзвінка у цій школі також немає: якщо діти втомилися, то повідомляють про це вчителя і той робить для них перерву. Щодня перед початком уроків учні обов' язково збираються на так звану «годину обговорень», коли можна говорити на будь-які теми.

Незважаючи на наявність подібних закладів освіти, думки психологів і педагогів щодо їх діяльності кардинально протилежні. Так, одні вважають, що навчання у спеціалізованій школі дійсно йде дітям на користь, адже вони розвивають у талановитій особистості закладені природою здібності. Інші ж, навпаки, стверджують, що ізолювати дітей у таких школах небезпечно: із них можуть вирости генії, у майбутньому непристосовані до звичайного життя. Чи зможуть вони в ньому вижити, чи будуть зрозумілі оточенню питання риторичні.

Навчаючи обдарованих дітей, учителі у Латвії, безперечно, також повинні мати високий рівень підготовки. Для того, щоб допомогти вчителеві підвищити свою кваліфікацію в роботі з обдарованими учнями, окрім професійної освіти, самоосвіти та самовдосконалення, діють курси із підвищення кваліфікації [2, с. 32]. Післядипломна освіта $€$ неодмінною складовою навчання й перепідготовки педагогів, що сприяє формуванню вчительської компетенції, необхідної в роботі з обдарованими учнями. На таких курсах можна отримати інформацію про останні новинки та нововведення в методиці викладання, додаткові знання 3 укладання авторських програм, розробок і використання на уроках активних методів навчання, поглибити знання $з$ психології про індивідуальні людські якості та нові методи діагностики тощо. Післядипломна освіта сприяє реалізації одного з трьох основних принципів психопедагогіки креативності - удосконалення знань та поєднання їх із практикою [2, с. 30]. До речі, у Латвії професійне підвищення кваліфікації вчителів грунтується на підтримці розвитку індивідуальної творчості та індивідуалізації процесу навчання.

Обдарована дитина схильна критично ставитися не тільки до себе, а й до оточуючих. Тому педагоги, які працюють 3 обдарованими дітьми, мають бути неабияк терпимі до критики загалом та до себе зокрема. Талановиті діти часто сприймають невербальні сигнали як прояв неприйняття себе оточуючими, внаслідок чого складається враження, що дитина - непосидюча, постійно відволікається та на все бурхливо реагує. У зв'язку з цим варто пам'ятати, що для таких дітей не існує стандартних вимог (на кшталт «все як у всіх»), їм складно бути конформістами, особливо, якщо наявні норми і правила йдуть врозріз із їхніми інтересами і здаються безглуздими. Для обдарованої дитини твердження, що «так прийнято», ніколи не було аргументом [3, с. 30].

Висновки. Отже, підтримка та супровід обдарованої дитини - це справа не одного дня, тижня чи місяця, а результат довготривалої наполегливої і систематичної праці як учителя, так і самої дитини. Розглядаючи особливості навчання обдарованих дітей у Латвії, варто зауважити, що дана проблема - неабияк важлива у прогресивному русі цивілізації загалом та соціально-економічному, культурному розвитку країни і визначенні їі місця на світовій арені зокрема.

Обдаровані діти сьогодні вважаються безцінним людським капіталом держави, які, завдяки своїй творчій діяльності в різних сферах життя суспільства, зможуть якісно вплинути на освітні та культурні процеси в національному та європейському контексті. Латвія в цілому створює всі соціальні умови для успішного кар'єрного просування талановитих людей як майбутньої національної еліти країни.

Подальші дослідження плануємо присвятити новим технологіям навчання, які сприятимуть розвитку інтелектуальної, творчої, предметної або лідерської обдарованості учнів.

\section{СПИСОК ВИКОРИСТАНОЇ ЛІТЕРАТУРИ}

1. Аксенова Э. А. Инновационные подходы к обучению одаренных детей за рубежом. Эйдос : интернет-журнал. 2007. № 1. URL: http://www.eidos.ru/ journal/2007/0115-9.htm (дата обращения: 30.04.2020).

2. Демченко О. П. Формування креативної компетентності майбутніх педагогів в контексті підготовки до роботи $з$ обдарованими дітьми. Молодий вчений. 2018. № 5.2 (57.2). С. 29-34.

3. Замелюк М. І., Денис Н. О. Обдарована дитина: психолого-педагогічні основи виявлення та розвитку : навч.-метод. посіб. Луцьк : Cit-друк, 2018. 120 с.

4. Замелюк М. І. Гуманізація освітнього простору навчального закладу як основа творчого розвитку особистості. Вісник Черкаського університету. Черкаси, 2013. № 40 (293). С. 47-50. (Серія «Педагогічні науки»).

5. Замелюк М., Пуш О., Триндюк В. Особливості психолого-педагогічної готовності педагогів до роботи $з$ обдарованими дітьми. Інноватика у вихованні. Рівне : РДГУ, 2020. Вип. 11. Т. 2. С. 129-138.

6. Замелюк М. Психолого-педагогічні погляди на феномен готовності до педагогічної творчості : матеріали V Міжнар. наук.-практ. конф. науковців, аспірантів та студентів. Актуальні проблеми соиіальної педагогіки, початкової та дошкільної освіти : зб. наук. праць. Луцьк : ПП Іванюк, 2014. С. 95-99.

7. Зуєв М. І. Доуніверситетська підготовка обдарованих учнів в європейських державах. Наукові записки Малої академії наук України. 2016. № 8. C. 70-79. URL: http://man.gov.ua/upload/activities/ Scientifik_note/Scientifik_note_JASU_8.pdf (дата звернення: 10.05.2020). 
8. Пріма Р., Замелюк М. І. М. Робота з обдарованими студентами: теоретико-прикладні аспекти. Вища освіта Украӥни. 2014. № 3 (додаток 2). Т. 2. C. 201-21. (Тематичний випуск «Педагогіка вищої школи: методологія, теорія, технології»).

9. Попова Л. В. Образовательные программы для одаренных в странах Европы. Психологическая наука и образование. 2009. № 4. С. 101-114.

10. Программы обучения и поддержки одаренных детей и молодежи. Психологическая наука и образование. 2011. № 4. С. 19-31.

11. Ткачишина Р. Обдарованість особистості у контексті вивчення проблеми соціальних стереотипів. URL: http://appsychology.org.ua/data/jrn/v6/i15/39. pdf (дата звернення: 10.05.2020).
12. Zameluk M. To the question off ormation of creative personality of a future teacher. Scientific-practical publication «Science. Education. Right. Management». Lodz: Foundation for education and science with outborders «FOR the FUTURE». 2015. № 4 (12). P. 246-256.

13. Prima R., Zameluk M. Twórczyrozwójdziecka w wiekupr zed szkolny mprzezśrodki bajkiautorskiej. Pracazbiorowa podredakcja Mirosława Nyczaj-Drag «Obraz Edukacji dziecka w Po/lsce i na Ukrainie» wydawnictwo internetowe e-bookowo, Wydanie I, 2015. C. 169-179.

Дата надходження до редакиіï: 12.06.2020 p. 